\title{
Enquete: Rundvisningen
}

Mange antropologer bekymrer sig, især når de skal udføre deres første feltarbejde, om det nu overhovedet vil være muligt at finde mennesker, der vil deltage i deres undersøgelse. Det viser sig dog sjældent at være et problem i Danmark. De fleste danskere er pæne og høflige mennesker, som gerne stiller sig til rådighed for forskningen med deres viden og erfaring. På den måde gæster man som antropolog mange menneskers hjem og opdager hurtigt, at skabelsen af data er et gensidigt projekt, og at forskeren ikke er alene om at bestemme, hvad projektet går ud på. I Danmark vil det første besøg i folks hjem ofte indebære en fremvisning af hjemmet, der af mange opfattes som en vigtig del af personen. Jeg har flere gange hørt udenlandske kolleger på ophold i Danmark studse over denne tradition, så måske er der en særlig dansk form for høflighed på spil her. Selv husker jeg en ganske bestemt rundvisning fra mit første feltarbejde.

Feltarbejdet fandt sted i forbindelse med en undersøgelse af sygdomsopfattelser blandt danske kræftpatienter og -behandlere. Vi var fire studerende, der arbejdede to og to på projektet, og ud over samtaler og deltagerobservation på hospitaler, besøgte vi også folk i deres hjem. En af de patienter vi fulgte, var en ældre mand med lungekræft, som vi har kaldt Werner. Både han og hans kone var fra første færd villige til at deltage $\mathrm{i}$ undersøgelsen og var meget meddelsomme om sygdomsforløbet, når vi talte med dem på hospitalet. De modsatte sig da heller ikke, da vi spurgte, om vi måtte komme og interviewe dem i hjemmet.

Vi troppede således op efter aftale en lørdag sidst på sommeren på familiens ejendom med tilhørende frugtplantage et sted i Nordsjælland. Vi blev budt velkommen, vist rundt i køkken, bryggers, stue og den udend $\varnothing$ rs terrasse og derefter budt på en drink ved sofabordet i dagligstuen sammen med to andre gæster, en svoger og svigerinde fra Ålborg. Kort efter gik damerne i køkkenet og forberedte frokosten, som stod på stegt ål, mens vi konverserede herrerne i stuen. Det var lidt vanskeligt at få de planlagte spørgsmål om sygdom og behandling bragt på bane i denne situation, og det var tydeligvis heller ikke meningen. Derimod fortalte Werner udførligt om sit livsværk, frugtplantagen, og lod os snart vide, at han havde arrangeret en rundvisning på „farmen“ for os. Der gik da heller ikke mange minutter, før en ung mand på en lille traktor med lad kørte ind på gårdspladsen. På ladet, der normalt ville være beregnet til at transportere frugtkasser, var der i dagens anledning monteret en storblomstret topersoners havesofa. Werner stak diskret den unge mand en hundredkroneseddel, mens vi blev beordret op i sofaen. Af sted gik det så op og ned mellem de lange rækker af solbær-, ribs-, stikkelsbær- og hyldebærbuske og videre til andre rækker med æble-, kirsebær- og blommetræer i imponerende antal. En lille regnbyge undervejs hindrede ikke, at vi også fik rabarberne at 
se. Turen sluttede efter en times tid ved et bugnende frugttræ, hvor vi fik udleveret et stor kurv med besked om at forsyne os rigeligt med de dejlige modne blommer. Da vi endelig kom tilbage til ejendommen med kurven fuld, insisterede Werner på endnu en rundvisning - denne gang i haven og på egen hånd - mens familien hyggede sig med ålene og snapsen ved frokostbordet i stuen. Derefter takkede han og konen for besøget og bød os farvel. Sygdomsopfattelser blev der ikke noteret meget om den dag.

Vibeke Steffen, lektor Institut for Antropologi Kфbenhavns Universitet 